\title{
PONDOK PESANTREN: Ciri Khas, Perkembangan, dan Sistem Pendidikannya
}

\author{
B. Marjani Alwi \\ Fakultas Agama Islam Universitas Muhammadiyah Makassar \\ Kampus: Jalan Sultan Alauddin Makassar \\ Email: marjanialwi@yahoo.co.id
}

\begin{abstract}
Abstrak:
Pondok pesantren sebagai lembaga pendidikan juga sebagai lembaga pengajaran agama dan sosial keagamaan, mulai dikenal di sepanjang pantai utara Jawa seperti di Gresik, Surabaya, Tuban, dan sebagainya. Beberapa ciri khas yang dimiliki oleh pondok pesantren secara umum yang masih dipertahankan sampai sekarang ini adalah kiai, santri, pengajaran kitab Islam klasik, masjid, dan pondok. Sistem pendidikan dan pengajaran di pondok pesantren diklasifikasi menjadi tiga tipe, yaitu pesantren tradisional, pesantren semi modern, dan pesantren modern.
\end{abstract}

\begin{abstract}
:
Boarding school as an educational institution as well as religious institution and religious social teaching have been known along the northern coast of Java, such as Gresik, Surabaya, Tuban, and other places. Some characteristic possessed by the boarding school in general is still maintained until now such as kiai, santri, teaching classical Islamic texts, mosques, and pondok (a place where santri live). The education system and teaching in boarding school are classified into three types, namely traditional boarding schools, semi-modern boarding school, and modern boarding schools.
\end{abstract}

\section{Kata kunci: \\ Pondok pesantren, Perkembangan, Sistem pendidikan}

ERA reformasi dan globalisasi yang serba modern mengakibatkan prilaku kehidupan masyarakat turut bergeser sehingga menimbulkan berbagai perubahan sosial yang bukan hanya melibatkan aspek lahiriah, tetapi juga mempengaruhi nilai keagamaan suatu masyarakat. Quraish Shihab menyatakan bahwa setiap masyarakat mempunyai ciri khas dan pandangan hidupnya, mereka melangkah berdasarkan kesadaran tentang hal itu, yang melahirkan watak dan kepribadiannya yang khas. ${ }^{1}$

Pelaksanaan ajaran Islam dalam kehidupan sehari-hari, terwujud dengan baik dan berkesinambungan apabila nilai agama terstruktur dan terpelihara dalam kehidupan pribadi dan masyarakat yang berawal dari keluarga. Firman Allah dalam QS al-Tahrim/ 66: 6 berbunyi:

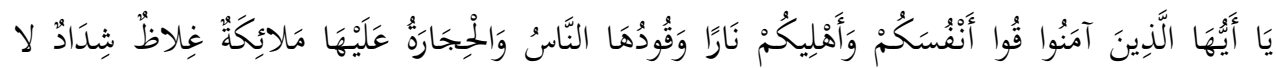

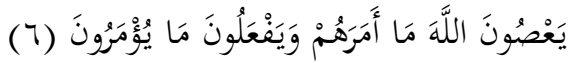

Hai orang-orang yang beriman, peliharalah dirimu dan keluargamu dari api neraka yang bahan bakarnya adalah manusia dan batu; penjaganya malaikat-malaikat yang kasar, keras, dan tidak mendurhakai Allah terhadap apa yang diperintahkan-Nya kepada mereka dan selalu mengerjakan apa yang diperintahkan. ${ }^{2}$ 
Ayat tersebut di atas menunjukkan bahwa Allah swt. memperingatkan kepada umat Islam utamanya para orangtua agar senantiasa menjaga, membimbing, mengasuh serta memelihara keluarga dengan baik, agar tidak sampai mendurhakai Allah swt. dalam segala segi kehidupan. Salah satu upaya untuk mempertahankan nilai ajaran agama disamping melalui kehidupan keluarga adalah melalui sistem pendidikan, antara lain melalui pendidikan pondok pesantren.

Tata nilai yang berkembang di pesantren bahwa seluruh aktifitas kehidupan adalah bernilai ibadah. Sejak memasuki lingkungan pesantren, seorang santri telah diperkenalkan dengan suatu model kehidupan yang bersifat keibadatan. Ketaatan seorang santri terhadap kiai merupakan salah satu manifestasi atas ketaatan yang dipandang sebagai ibadah. ${ }^{3}$

Keberadaan pondok pesantren di Indonesia, dalam perkembangannya sangat berpengaruh terhadap masyarakat di sekitarnya, terutama dalam hal pendidikan. Hal ini disebabkan bahwa dari sejak awal berdirinya pesantren disiapkan untuk mendidik dan menyebarkan ajaran Islam kepada masyarakat melalui pengajian, baik dengan sistem tradisional maupun modern. ${ }^{4}$

Pesantren pada umumnya memiliki kesamaan antara satu pesantren dengan pesantren yang lain, yaitu adanya kesamaan ideologi serta memiliki kesamaan referensi dengan metode pengajaran yang sama, sehingga menjadikan pesantren memiliki kekuatan yang cukup signifikan dan dapat diperhitungkan oleh siapapun juga. Kekuatan yang dimiliki oleh pesantren diantaranya karena pondok pesantren tumbuh dan diakui oleh masyarakat sekitar dengan sistem asrama. Santri menerima pendidikan agama melalui sistem pengajian atau madrasah yang sepenuhnya berada di bawah kedaulatan kepemimpinan seorang kiai, dengan ciri khas yang bersifat kharismatik serta independen dalam segala hal.

Perkembangan pendidikan pondok pesantren merupakan perwujudan dari kebutuhan masyarakat akan suatu sistem pendidikan alternatif. Keberadaan pondok pesantren tersebut sebagai lembaga pendidikan, juga sebagai lembaga dakwah dan syiar Islam serta sosial keagamaan.

Tulisan ini akan menguraikan pondok pesantren dengan ciri khasnya tersendiri, perkembangannya, dan juga sistem pendidikan yang diterapkan dalam proses pembelajarannya. Pondok pesantren sebagai lembaga pendidikan telah mapan dan berhasil dalam mengaktualisasikan nilai ajaran Islam dalam kehidupan sehari-hari, sehingga dapat menjadi kebanggaan bagi umat Islam.

\section{PEMBAHASAN}

\section{Ciri Khas Pondok Pesantren}

Perkataan pesantren berasal dari kata "santri", dengan awalan "pe" dan akhiran "an" yang mempunya arti asrama tempat santri atau tempat murid belajar mengaji. ${ }^{5}$ Santri adalah orang yang mendalami agama Islam, orang yang beribadat dengan sungguh-sungguh, orang yang saleh. ${ }^{6}$ 
Johns yang dikutip Dhofier berpendapat bahwa istilah santri berasal dari bahasa Tamil artinya guru mengaji. C.C. Berg berpendapat bahwa istilah tersebut berasal dari istilah shastri yang dalam bahasa India berarti orang yang tahu buku suci agama Hindu, atau seorang sarjana ahli kitab suci agama Hindu. Kata shastri tersebut berasal dari kata shastra yang berarti buku suci, buku agama atau buku tentang ilmu pengetahuan. ${ }^{7}$

Santri dalam Soegarda mengartikan orang yang belajar agama Islam, sehingga pesantren mempunyai arti tempat orang berkumpul untuk belajar agama Islam. ${ }^{8}$ Nurcholish Madjid menyatakan bahwa kata santri berasa dari bahasa Jawa yaitu "cantrik" yang berarti seseorang yang selalu mengikuti seorang guru kemana pergi. ${ }^{9}$

Berkaitan dengan istilah pondok pesantren, maka sebelum tahun 1960-an istilah "pondok" lebih dikenal sebagai pusat pendidikan pesantren. Menurut Zamakhsyari bahwa istilah pondok kemungkinan berasal dari pengertian asrama para santri atau tempat tinggal yang dibuat dari bambu, atau mungkin berasal dari kata Arab funduq yang berarti hotel atau asrama. ${ }^{10}$ Kata pondok dalam Kamus Besar Bahasa Indonesia adalah bangunan untuk tempat sementara; rumah; bangunan tempat tinggal yang berpetak yang berdinding bilik dan beratap rumbia; madrasah dan asrama (tempat mengaji, belajar agama Islam). ${ }^{11}$ Istilah pondok ataupun pesantren pada dasarnya memiliki makna yang sama yaitu tempat tinggal santri, namun penggunaan pondok pesantren sering digunakan oleh masyarakat yang dapat dipahami sebagai penguatan makna saja.

Pesantren secara terminologi didefinisikan sebagai lembaga pendidikan tradisional Islam untuk mempelajari, memahami, mendalami, menghayati, dan mengamalkan ajaran Islam dengan menekankan pentingnya moral keagamaan sebagai pedoman perilaku sehari-hari. ${ }^{12}$ Menurut Syukri Zarkasyi, pesantren adalah lembaga pendidikan Islam dengan sistem asrama dan di dalamnya ada yang bertindak sebagai pendidik dan sentral figurnya yaitu kiai, ajengan atau tuan guru, dan ada santri, asrama, ruang belajar, dan masjid sebagai sentralnya. ${ }^{13}$

Pesantren sebagai lembaga pendidikan memiliki lima elemen dasar tradisi pesantren, yaitu pondok, masjid, santri, pengajaran kitab Islam klasik, dan kiai. ${ }^{14}$ Pendapat lain menyatakan bahwa dalam lembaga pendidikan Islam yang disebut pesantren selalu terdapat unsur kiai yang mengajar dan mendidik, santri yang belajar dari kiai, masjid serta pondok tempat tinggal para santri. ${ }^{15}$ Elemen dasar tersebut masih tetap bertahan dalam perkembangannya sampai sekarang ini. Ciri pesantren tersebut diuraikan berikut ini:

\section{Kiai}

Kiai atau pengasuh pondok pesantren adalah elemen yang sangat esensial bagi suatu pesantren. Pada umumnya, sosok kiai sangat berpengaruh, kharismatik, dan berwibawa sehingga sangat disegani oleh masyarakat di lingkungan pondok pesantren. Selain itu, biasanya kiai pondok pesantren adalah sekaligus sebagai penggagas dan pendiri dari pesantren tersebut. Dengan demikian, sangat wajar apabila dalam pertumbuhannya, pesantren sangat tergantung pada peran seorang kiai. ${ }^{16}$ 
Menurut asal-usulnya, perkataan kiai digunakan untuk tiga jenis gelar yang saling berbeda, yaitu:

1. Sebagai gelar kehormatan pada barang yang dianggap keramat, misalnya "Kiai Garuda Kencana" yang digunakan untuk sebutan Kereta Emas yang berada di Keraton Yogyakarta.

2. Gelar kehormatan untuk orang-orang tua pada umumnya.

3. Gelar yang diberikan oleh masyarakat kepada seorang ahli agama Islam yang memiliki atau menjadi pemimpin pesantren dan mengajarkan kitab Islam klasik kepada para santrinya. Selain gelar kiai, ia juga sering disebut seorang alim (orang yang dalam pengetahuan Islamnya). ${ }^{17}$

Predikat kiai sebagai seorang yang ahli agama diberikan oleh masyarakat yang mengakui kealiman seseorang. Tuntunan dan kepemimpinannya diterima dan diakui oleh masyarakat, bukan diperoleh dari sekolah. Kiai tidak memerlukan ijazah, tetapi kealiman, kesalehan, dan kemampuan mengajar santri dengan kitab kuning. Oleh karena itu, masyarakatlah yang memberi penghormatan kepada seseorang tersebut. ${ }^{18}$

Para kiai dengan kelebihannya dalam penguasaan pengetahuan Islam, seringkali terlihat sebagai orang yang senantiasa dapat memahami keagungan Tuhan dan rahasia alam sehinggga mereka dianggap memiliki kedudukan yang tak terjangkau, terutama oleh kebanyakan orang awam. ${ }^{19}$

Kebanyakan masyarakat Islam tradisional di Jawa, kiai di pesantren dianggap sebagai figur sentral yang diibaratkan kerajaan kecil yang mempunyai wewenang dan otoritas mutlak di lingkungan pesantren. Tidak seorangpun santri atau orang lain yang berani melawan kekuasaan kiai (dalam lingkungan pesantrennya), kecuali kiai lain yang lebih besar pengaruhnya. ${ }^{20}$

Kiai sebagai pengasuh pondok pesantren diposisikan sebagai top leader yang menjadi panutan bagi santrinya. Oleh karena itu, segala bentuk kebijakan pesantren berada di tangan kiai, terkhusus yang berkaitan dengan pembentukan suasana kepesantrenan.

\section{Santri}

Santri adalah siswa atau murid yang belajar dan merupakan salah satu elemen penting dalam suatu lembaga pesantren. Seorang ulama dapat disebut kiai apabila memiliki pesantren dan santri yang tinggal dalam pesantren untuk mempelajari kitab Islam klasik. Dengan demikian, eksistensi kiai biasanya juga berkaitan dengan adanya santri di pesantren. ${ }^{21}$

Menurut tradisi pesantren, santri terdiri dari dua kategori:

1. Santri mukim, yaitu murid yang berasal dari daerah yang jauh dan menetap dalam kelompok pesantren. Santri mukim yang paling lama tinggal (santri senior) di pesantren biasanya merupakan satu kelompok tersendiri yang bertanggung jawab mengurusi kepentingan pesantren sehari-hari. Santri senior memiliki kesempatan untuk membina santri yang datang belakangan bahkan bertanggung jawab mengajar santri muda tentang kitab dasar dan menengah. 
2. Santri kalong, yaitu murid yang berasal dari desa di sekitar pesantren dan tidak menetap dalam pesantren. Santri kalong memiliki rumah orang tua yang letaknya tidak jauh dari pesantren, sehingga memungkinkan mereka pulang setiap hari ke tempat tinggal masing-masing setelah aktivitas pembelajaran berakhir. ${ }^{22}$

Selain kategori santri mukim dan santri kalongan di dalam pesantren, ada juga istilah "santri kelana". Santri kelana adalah santri yang selalu berpindah dari satu pesantren ke pesantren lainnya hanya untuk memperdalam ilmu agama. Santri kelana selalu berambisi untuk memiliki ilmu dan keahlian tertentu dari kiai yang dijadikan tempat belajar atau dijadikannya guru. ${ }^{23}$

Ada beberapa alasan seorang santri pergi dan menetap di suatu pesantren, yaitu:

1. Ia ingin mempelajari kitab lain yang membahas Islam secara lebih mendalam di bawah bimbingan kiai yang memimpin pesantren.

2. Ia ingin memperoleh pengalaman kehidupan pesantren, baik dalam bidang pengajaran, keorganisasian maupun hubungan dengan pesantren terkenal.

3. Ia ingin memusatkan studinya di pesantren tanpa disibukkan oleh kewajiban sehari-hari di rumah keluarganya. Selain itu, dengan tinggal di pesantren yang sangat jauh dari rumahnya sendiri, maka ia tidak mudah pulang-balik meskipun terkadang menginginkannya. ${ }^{24}$

Pada perkembangannya, santri kalong sudah jarang ditemukan dalam suatu pondok pesantren. Santri yang menetap di pondok berasal dari berbagai daerah baik dalam negeri ataupun luar negeri, yang dapat meninggalkan pondok ketika liburan ataupun suatu keadaan mendesak yang seorang santri harus kembali ke rumahnya atau negerinya.

\section{Pengajaran kitab Islam klasik}

Ciri spesifik sebuah pondok pada umumnya adalah adanya pengajaran yang sering disebut pengajian kitab klasik, yang populer dengan sebutan "kitab kuning". Ciri yang dimaksud terdapat pada pondok pesantren,baik tradisional maupun yang sudah modern. ${ }^{25}$ Kitab klasik yang diajarkan di dalam pesantren adalah produk dari ulama Islam pada zaman pertengahan, dan ditulis dalam bahasa Arab tanpa harakat. Olehnya itu, salah satu kriteria seseorang disebut kiai atau ulama adalah memiliki kemampuan membaca dan mensyarahkan kitab klasik. Syarat bagi santri untuk dapat membaca dan memahami kitab kuning tersebut adalah dengan memahami dengan baik antara lain ilmu nahu, saraf, dan balagah (ilmu bahasa Arab). ${ }^{26}$

Saat ini, meskipun kebanyakan pesantren telah mengakomodasi sejumlah mata pelajaran umum untuk diajarkan di pesantren, tetapi pengajaran kitab Islam klasik tetap diberikan sebagai upaya untuk meneruskan tujuan utama pesantren. Kitab klasik yang diajarkan di pesantren dapat digolongkan ke dalam delapan kelompok jenis pengetahuan, yaitu 1) nahwu (syntaz) dan shorof (morfologi), 2) fikih, 3) ushulu al-figh, 4) hadis, 5) tafsir, 6) tauhid, 7) tasawuf dan etika, dan 8) cabang lain seperti tarikh dan balaghah. Selain itu, kitab tersebut memiliki pula karakteristik teks yang sangat pendek sampai teks yang terdiri dari beberapa jilid dan tebal. Karakteristik tersebut 
dibagi ke dalam tiga kelompok, yaitu kitab dasar, kitab tingkat menengah, dan kitab besar. ${ }^{27}$

\section{Masjid}

Masjid merupakan elemen yang tidak dapat dipisahkan dengan pesantren dan dianggap sebagai tempat yang paling tepat untuk mendidik para santri, terutama dalam praktik salat lima waktu, khutbah dan salat Jumat, dan pengajaran kitab Islam klasik. ${ }^{28}$ Sejak zaman Nabi Muhammad saw., masjid telah menjadi pusat pendidikan Islam. Kaum muslimin selalu menggunakan masjid untuk tempat beribadah, pertemuan, pusat pendidikan, aktivitas administrasi dan kultural. ${ }^{29}$ Kedudukan masjid sebagai pusat pendidikan dalam tradisi pesantren merupakan manifestasi universalisme dari sistem pendidikan Islam tradisional. ${ }^{30}$

Lembaga pesantren selalu memelihara tradisi, bahwa kiai mengajar santri di masjid dan menganggap masjid sebagai tempat yang paling tepat untuk menanamkan disiplin para santri dalam mengerjakan kewajiban salat lima waktu, memperoleh pengetahuan agama, dan kewajiban agama yang lainnya. ${ }^{31}$ Selain itu, masjid dan kiai adalah dua hal yang memiliki keterkaitan erat satu dengan lainnya. Masjid digunakan oleh kiai sebagai pusat kegiatan yang bukan hanya dalam bentuk transmisi ilmu Islam, tetapi juga adanya hubungan emosional antara kiai dengan santri yang menghasilkan penghormatan santri secara tulus kepada sang kiai. ${ }^{32}$

Pada dasarnya, masjid tidak hanya sebatas tempat ibadah saja ataupun sebagai tempat terjadinya proses pembelajaran antara seorang kiai dan para santri, akan tetapi juga sebagai tempat pertemuan ataupun pusat kegiatan lainnya.

\section{Pondok}

Pondok atau tempat tinggal para santri merupakan ciri khas tradisi pesantren yang membedakannya dengan sistem pendidikan lainnya. Ada tiga alasan utama pesantren harus menyediakan asrama bagi para santri. Pertama, para santri tertarik dengan kemasyhuran atau kedalaman ilmu sang kiai, sehingga mereka ingin mendekatkan diri mereka kepada sang kiai. Kedua, hampir semua pesantren berada di desa yang tidak menyediakan perumahan untuk menampung para santri. Ketiga, santri menganggap kiainya seolah-olah bapaknya sendiri, sedangkan kiai menganggap para santri sebagai titipan Tuhan yang harus senantiasa dilindungi. Salah satu perlindungan yang diberikan oleh kiai adalah dengan menyediakan pemondokan bagi para santri. ${ }^{33}$

Pada umumnya, pondok pesantren memiliki ciri-ciri tersebut di atas dengan tujuan untuk mencetak calon ulama dan para mubalig yang tabah, tangguh, dan ikhlas dalam menyiarkan agama Islam. Pondok pesantren saat ini, masih tetap mempertahankan fungsi pondok tersebut untuk mencetak calon ulama dan ahli agama.

\section{Perkembangan Pondok Pesantren di Indonesia}

Tokoh atau orang pertama yang membangun pondok pesantren sebagai tempat mendidik dan menggembleng para santri di tanah Jawa adalah Maulana Malik Ibra- 
him atau dikenal dengan Sunan Gresik (w. 1419 H). Hasil penelusuran sejarah menemukan bukti kuat yang menunjukkan cikal bakal pendirian pesantren pada periode awal terdapat di daerah sepanjang pantai utara Jawa, seperti Giri (Gresik), Ampel Denta (Surabaya), Bonang (Tuban), Kudus, Lasem, Cirebon, dan sebagainya. ${ }^{34}$

Kehadiran pondok pesantren di tengah-tengah masyarakat selain sebagai lembaga pendidikan juga sebagai lembaga penyiaran agama dan sosial keagamaan. Salah satu sikap yang dilakukan oleh para ulama dari kalangan pondok pesantren adalah adanya bentuk perlawanan secara terang-terangan terhadap pemerintah Belanda pada tahun 1888 M, seperti perlawanan Kiai Mojo di Tegalrejo, Kiai Rifa'ie di Kalisasak Batang, kiai Haji Zaenal Musthafa di Sukamanah Tasikmalaya. ${ }^{35}$ Terdapat bukti sejarah bahwa tidak sedikit putra bangsa ditempa di pondok pesantren, mereka tidak hanya terlibat perjuangan fisik melawan penjajah, tetapi turut aktif dalam mempertahankan dan mengisi era kemerdekaan. Oleh karena itu, menurut Amin Haedari bahwa tidak berlebihan jika pada tahun 1959-1965 pesantren disebut sebagai alat revolusi dan penjaga keutuhan Negara Kesatuan Republik Indonesia. ${ }^{36}$

Pondok pesantren sebagai lembaga pendidikan, pernah menghadapi tantangan pada masa kemerdekaan Indonesia yaitu setelah penyerahan kedaulatan pada tahun 1949. Pemerintah Republik Indonesia mendorong pembangunan sekolah umum seluas-luasnya dan membuka secara luas jabatan dalam administrasi modern bagi bangsa Indonesia yang terdidik dalam sekolah umum tersebut. Dampak dari kebijaksanaan yang dikeluarkan oleh pemerintah adalah kekuatan pesantren sebagai pusat pendidikan Islam di Indonesia menurun. Anak muda yang tertarik mengikuti pendidikan pesantren tidak sebanyak anak muda yang mengikuti pendidikan sekolah umum. ${ }^{37}$

Pada perkembangannya, pondok pesantren dapat bertahan dengan berbagai cara, antara lain menyelenggarakan sekolah umum dalam lingkungan pondok pesantren. Zamakhsyari Dhofier menyebutkan bahwa lembaga pondok pesantren dapat dikelompokkan dalam dua tipe besar, yaitu: 1) tipe lama (klasik) yang inti pendidikannya mengajarkan kitab Islam klasik, 2) tipe baru, yaitu mendirikan sekolah umum dan madrasah yang mayoritas mata pelajaran yang dikembangkannya bukan kitab Islam klasik. ${ }^{38}$

Dewasa ini, penambahan jumlah pondok pesantren sudah berkembang sangat pesat dengan melihat tabel berikut ini:

Tabel 1

Perkembangan Pondok Pesantren di Indonesia tahun 1982 - $2011^{39}$

\begin{tabular}{|c|c|}
\hline Tahun & Jumlah Pondok Pesantren \\
\hline 1982 & 4.195 \\
\hline 1987 & 6.176 \\
\hline 1998 & 7.616 \\
\hline 2008 & 21.521 \\
\hline $2008-2011$ & 28.000 \\
\hline
\end{tabular}




\section{Sistem Pendidikan Pondok Pesantren di Indonesia}

Berkaitan dengan sistem pendidikan yang diterapkan di pondok pesantren, maka sebagai bagian struktur internal pendidikan Islam Indonesia, pondok pesantren mempunyai kekhasan, terutama dalam fungsinya sebagai institusi pendidikan, lembaga dakwah, bimbingan kemasyarakatan, dan bahkan perjuangan. ${ }^{40}$ Beberapa pola umum pendidikan Islam tradisional diidentifikasikan sebagai berikut:

1. Adanya hubungan yang akrab antara kiai dan santri

2. Tradisi ketundukan dan kepatuhan seorang santri terhadap kiai

3. Pola hidup sederhana

4. Kemandirian atau independensi

5. Berkembangnya iklim dan tradisi tolong menolong dan suasana persaudaraan.

6. Disiplin ketat

7. Berani menderita untuk mencapai tujuan

8. Kehidupan dengan tingkat religiusitas yang tinggi. ${ }^{41}$

Ciri khas pondok pesantren sebagai lembaga pendidikan Islam tradisional adalah pemberian pelajaran agama versi kitab Islam klasik berbahasa Arab, mempunyai teknik pengajaran yang dikenal dengan metode sorogan dan bandongan atau wetonan, mengedepankan hapalan serta menggunakan sistem halaqah. ${ }^{42}$

Selain halaqah, dalam dunia pondok pesantren juga dikenal beberapa metodologi pengajaran sebagai berikut:

\section{Hapalan (tahfiz)}

Hapalan pada umumnya diterapkan pada mata pelajaran yang bersifat nadham (syair) bukan natsar (prosa) dan biasanya terbatas pada ilmu kaidah bahasa Arab. Metode ini biasanya santri diberikan tugas untuk menghafal beberapa bait atau baris kalimat dari sebuah kitab, untuk kemudian membacakannya di depan kiai/ustad.

Aplikasi metode hapalan diterapkan dengan dua cara. Pertama, setiap kali tatap muka, santri diharuskan membacakan tugas hafalnnya dihadapan kiai, jika ia hafal dengan baik maka ia diperbolehkan untuk melanjutkan tugas hapalan berikutnya. Sebaliknya, jika santri belum berhasil menghafal maka ia harus mengulangi lagi sampai lancar untuk disetorkan kembali pada pertemuan yang akan datang.

\section{Hiwar atau musyawarah}

Hiwar merupakan aspek dari proses pembelajaran di pondok pesantren yang metodenya hampir sama dengan metode diskusi umum. Kegiatan hiwar di pondok pesantren merupakan suatu keharusan bagi santri, jika tidak mengikuti kegiatan ini maka santri akan dikenakan sanksi.

Pada pelaksanaan hiwar, para santri melakukan kegiatan belajar secara kelompok untuk membahas materi kitab yang telah diajarkan oleh kiai/ustad. Para santri tidak hanya membahas topik atau sub topik bahasan kitab saja, tetapi memperluas cakupan pembahasan tentang lafaz dan kalimat ditinjau dari gramatika bahasa Arab. 


\section{Metode Bahts al-Masail (Muzakarah)}

Muzakarah merupakan pertemuan ilmiah untuk membahas masalah diniyah, seperti ibadah, aqidah, dan permasalahan agama lainnya. Metode ini tidak jauh berbeda dengan metode musyawarah. Muzakarah pada umumnya hanya diikuti oleh para kiai atau para santri. Muzakarah dibedakan menjadi dua macam, yaitu:

1. Muzakarah yang diadakan antar sesama kiai atau ustad. Pada tipe ini, disediakan kitab besar yang merupakan rujukan utama serta dilengkapi dengan dalil dan metode istimbath (pengambilan hukum) yang lengkap. Metode ini bertujuan untuk memecahkan permasalahan agama dan kemasyarakatan yang timbul, selain itu untuk memperdalam pengetahuan agama.

2. Muzakarah yang diadakan antar sesama santri yang biasanya dipimpin oleh ustad atau santri senior yang ditunjuk oleh kiai. Tujuan pelaksanaan kegiatan ini adalah untuk melatih para santri dalam memecahkan masalah dengan menggunakan rujukan yang jelas, dan melatih santri tentang cara berargumentasi dengan menggunakan nalar yang lurus.

\section{Fath al-Kutub}

Fath al-kutub merupakan kegiatan latihan membaca kitab (terutama kitab klasik) yang pada umumnya ditugaskan kepada santri senior di pondok pesantren. Fath alkutub merupakan wahana aktualisasi kemampuan para santri, khususnya dalam penguasaan ilmu kaidah bahasa Arab dan ilmu keagamaan lainnya sesuai dengan materi kitab yang ditugaskan untuk dibaca oleh kiai. Biasanya, fath al-kutub dikhususkan bagi santri senior yang akan menyelesaikan pendidikannya di pondok pesantren.

\section{Muqaranah}

Metode muqaranah adalah metode yang terfokus pada kegiatan perbandingan, baik perbandingan materi, paham (mazhab), metode maupun perbandingan kitab, dan umumnya metode ini diterapkan pada kelas santri senior saja. Metode muqaranah ini kemudian dibagi dalam dua hal, yaitu muqoronat al-adyan untuk perbandingan ajaran agama dan muqoronat al-mazahib untuk perbandingan paham atau aliran.

\section{Muhawarah atau Muhadasah}

Muhawarah adalah latihan bercakap dengan menggunakan bahasa Arab. Aplikasi metode muhawarah ini dengan mewajibkan para santri untuk berbicara dengan menggunakan bahasa Arab, baik dengan sesama santri maupun dengan para ustad atau kiai di pondok pesantren. ${ }^{43}$

Metode muhawarah pada umumnya dilakukan melalui beberapa langkah, yaitu:

1. Para santri diberikan buku panduan yang berisi daftar kosa kata dalam bahasa Arab, contoh percakapan, dan aturan lainnya;

2. Para santri diwajibkan menghafal sejumlah kosa kata dari buku panduan dan biasanya diberikan target harian;

3. Kegiatan pembelajaran yang dilakukan secara kelompok dengan dipandu oleh seorang ustad berdasarkan jadwal yang telah ditentukan ssebelumnya secara rutin; 
4. Ustad melakukan tanya jawab dengan para santri dengan menggunakan bahasa Arab, atau dua santri memperagakan tanya jawab dihadapan santri lain secara bergiliran;

5. Pada pondok pesantren yang menjadikan bahasa Arab atau Inggeris sebagai alat komunikasi sehari-hari, latihan percakapan tidak hanya dilakukan di kelas saja, tetapi di mana dan kapan saja selama berada dalam lingkungan pondok pesantren;

6. Pesantren biasanya menciptakan sebuah lingkungan bahasa dengan memberikan nama benda dan tempat di lingkungan pesantren dengan menggunakan bahasa Arab atau Inggeris. ${ }^{44}$

Selanjutnya, Marwan Saridjo menyebutkan bahwa metode yang lazim dipergunakan dalam pondok pesantren yang sampai saat ini masih dipraktekkan adalah:

1. Wetonan, yaitu metode yang para santri mengikuti pelajaran dengan duduk di sekeliling kiai yang menerangkan pelajaran secara kuliah, sedangkan santri menyimak kitab dan membuat catatan. Weton berasal dari kata wektu (Jawa) yang berarti waktu, sebab pengajian tersebut diberikan pada waktu tertentu yaitu sebelum dan atau sesudah melakukan salat fardu.

2. Sorogan, yaitu metode yang santri menghadap guru seorang demi seorang dengan membawa kitab yang akan dipelajari. Kiai membaca pelajaran berbahasa Arab kemudian menerjemahkan dan menerangkan maksudnya. Santri menyimak kemudian kiai mengesahkan kitab santri tersebut yang menunjukkan bahwa ilmu yang diberikan oleh kiai telah dipelajari. Istilah sorogan berasal dari kata sorog (Jawa) yang berarti menyodorkan kitabnya di hadapan kiai dan pembantunya. 45

Sebagian ahli pendidikan mengklasifikasikan perkembangan sistem pendidikan pondok pesantren, yaitu:

1. Pondok pesantren yang hanya terdiri dari masjid dan rumah kiai. Pesantren ini sangat sederhana, dan pada umumnya berada pada tingkat permulaan berdirinya pondok pesantren. Para kiai menggunakan masjid atau rumahnya sebagai tempat para santri belajar kitab dengan lebih banyak menggunakan metode hapalan dan metode tuntunan. Awal berdirinya pesantren, pengajaran yang diterapkan dikenal dengan metode bandongan dan sorogan.

2. Pesantren memiliki masjid, rumah kiai, dan asrama tempat tinggal santri serta menyelenggarakan pengajian kitab klasik dengan metode hapalan, tuntunan, dan resitasi.

3. Pesantren yang selain memiliki komponen pesantren tradisional, juga menyelenggarakan pendidikan formal seperti madrasah dalam berbagai tingkat. Sistem pesantren dan sistem persekolahan berjalan saling melengkapi antara keduanya.

4. Pesantren yang telah memiliki komponen pola ketiga, juga mengembangkan pendidikan keterampilan seperti peternakan, kerajinan rakyat, koperasi, sawah, dan ladang.

5. Pesantren yang telah berkembang dan maju disebut pondok pesantren modern. Pesantren modern telah memiliki perpustakaan, dapur umum, ruang tamu, ruang 
makan, kantor administrasi, toko atau koperasi, gedung pertemuan, kamar mandi dan WC, dan laboratorium yang memadai. Aktifitas pesantren modern adalah pengajian kitab, menyelenggarakan madrasah dan sekolah umum dari tingkat dasar hinggap pendidikan tinggi serta pendidikan keterampilan dan juga program pengembangan lingkungan. ${ }^{46}$

Aktivitas pendidikan yang dikembangkan di dalam pondok pesantren dapat diklasifikasikan dalam beberapa tipe, yaitu:

1. Pesantren yang hanya menyelenggarakan pengajian kitab dengan sistem sorogan, bandongan, dan wetonan (pesantren tradisional).

2. Pesantren yang menyelenggarakan pendidikan campuran antara sistem pengajaran kitab tradisional dengan madrasah formal dan mengadopsi kurikulum pemerintah (pesantren semi modern).

3. Pesantren yang menyelenggarakan pola campuran antara sistem pengajian kitab tradisional, sistem madrasah, dan sistem sekolah umum dengan mengadopsi kurikulum pemerintah (Departemen Agama dan Departemen Pendidikan dan Kebudayaan) dan ditambah dengan kurikulum muatan lokal (pesantren modern). ${ }^{47}$

Pondok pesantren dengan sistem pendidikan dan pengajaran yang memadukan antara kurikulum lokal dan kurikulum pemerintah telah diterapkan di berbagai pondok pesantren di Indonesia. Pembauran sistem pendidikan tersebut dalam rangka untuk merealisasikan tujuan pendidikan nasional.

Zamakhsyari mengklasifikasikan pesantren dengan jumlah santri dan pengaruhnya sebagai indikator. Pertama, pesantren yang tergolong kecil mempunyai jumlah santri di bawah seribu dan pengaruhnya terbatas pada tingkat kabupaten. Kedua, pesantren menengah biasanya mempunyai santri antara 1.000 sampai 2.000 orang. Ketiga, pesantren besar yang memiliki santri lebih dari 2.000 yang berasal dari berbagai kabupaten dan propinsi. ${ }^{48}$

Pondok pesantren sebagai lembaga pendidikan Islam tradisional mempunyai beberapa kelebihan yang telah diterapkannya, yaitu:

1. Mampu menanamkan sikap hidup universal secara merata dengan tata nilai agama yang diberlakukan di pondok pesantren.

2. Mampu memelihara tata nilai pondok pesantren hingga teraplikasikan dalam segala aspek kehidupan di sepanjang pejalanan kehidupan seorang santri. ${ }^{49}$

Kelemahan pola umum pendidikan Islam tradisional di pondok pesantren meliputi beberapa hal, yaitu:

1. Tidak mempunyai perencanaan yang rinci dan rasional bagi jalannya proses pembelajaran.

2. Tidak mempunyai kurikulum yang terarah sehingga diharapkan dapat mempermudah santri dalam memahami pelajaran yang akan disampaikan.

3. Tidak mempunyai standar khusus yang membedakan secara jelas hal yang diperlukan dan tidak diperlukan dalam sebuah jenjang pendidikan. Pedoman yang digunakan hanya mengajarkan bagaimana penerapan hukum syara' dalam kehidu- 
pan, sedangkan nilai pendidikan, termasuk filsafat pendidikan masih cenderung terabaikan. ${ }^{50}$

Seiring berjalannya waktu, banyak pesantren tradisional yang telah memodernisasikan pondoknya sebagai pesantren modern. Husni Rahim menyatakan bahwa pondok pesantren terdiri dari dua kategori, yaitu pondok pesantren salafiyah dan khalafiyah. Pondok pesantren khalafiyah mengadopsi sistem pendidikan klasikal dengan kurikulum tertata dan mengintegrasikan pengetahuan umum. Menurut Husni, perkembangan terakhir tampaknya bahwa jenis pondok pesantren salafiyah telah berkurang yang diperkirakan tinggal 5.512 pondok pesantren dari 11.211 pondok pesantren yang ada di Indonesia. ${ }^{51}$

Pada dasarnya pondok pesantren tradisional bertujuan untuk mencetak calon ulama dan para muballig yang sanggup berkorban dalam menyiarkan agama Islam, dengan sistem pendidikan yang hanya bersifat pengajian kitab saja. Pada perkembangan selanjutnyanya, pondok pesantren saat ini telah memasukkan kurikulum pemerintah sebagai bagian yang tidak terpisahkan dari sistem pendidikannya. Lembaga pondok pesantren masih tetap menjadi salah satu gudang mencetak calon ulama yang diharapkan mampu menjadi pemimpin masa depan yang memiliki tanggungjawab terhadap kelangsungan dan kejayaan agama Islam.

\section{SIMPULAN}

Pembahasan mengenai pondok pesantren tentang ciri khas, perkembangan, dan sistem pendidikannya, dapat disimpulkan sebagai berikut:

Ada beberapa ciri khas yang identik dengan pondok pesantren yang masih tetap bertahan sampai sekarang ini adalah kiai, santri, pengajaran kitab Islam klasik, masjid, dan pondok. Kehadiran dan perkembangan pondok pesantren sebagai salah satu lembaga pendidikan di Indonesia, mengalami peningkatan yang cukup signifikan utamanya dalam perkembangan terakhir ini.

Perkembangan lembaga pondok pesantren terbagi atas dua kelompok, yaitu: 1) tipe lama (klasik) yang inti pendidikannya mengajarkan kitab Islam klasik, 2) tipe ba$\mathrm{ru}$, yaitu mendirikan sekolah umum dan madrasah yang mayoritas mata pelajaran yang dikembangkannya bukan kitab Islam klasik.

Sistem pendidikan dan pengajaran di pondok pesantren terdiri atas tahfiz, hiwar, bahts al-masaail, fath al-kutub, muqoranah, dan muhadatsah. Pondok pesantren dapat diklasifikasikan menjadi tiga tipe, yaitu pesantren tradisional, pesantren semi modern, dan pesantren modern.

Pondok pesantren yang berusaha mencetak insan muslim, membela dan mempertahankan nilai ajaran agama Islam dalam kehidupan bermasyarakat, berbangsa, dan bernegara, selayaknya tetap eksis di tengah masyarakat Indonesia. Upaya tersebut dilakukan dengan tetap mempertahankan nilai ajaran Islam yang murni tanpa diracuni oleh unsur yang lain. 


\section{CATATAN AKHIR}

1. M. Quraish Shihab, Wawasan al-Qur'an, Cet. II; Bandung: Mizan, 1996, h. 320.

2. Departemaen Agama RI, Al-Qur'an dan Terjemahnya, Bandung: CV Diponegoro, 2010, h. 560.

3. M. Quraish Shihab, Membumikan al-Qur'an, Bandung: Mizan, 1992, h. 257.

4. Ibid., h. 97.

5. Tim Redaksi Kamus Besar Bahasa Indonesia, Kamus Besar Bahasa Indonesia, Edisi II; Jakarta: Balai Pustaka, 1991, h. 762.

6. Ibid., h. 878 .

7. Zamakhsyari Dhofier, Tradisi Pesantren: Studi Pandangan Hidup Kiai dan Visinya Mengenai Masa Depan Indonesia, Cet. IX; Jakarta: LP3ES, 2011, h. 41.

8. Soegarda Poerbakawatja, Ensiklopedi Pendidikan, Jakarta: Gunung Agung, 1976, h. 223.

9. Nurcholish Madjid, Bilik-Bilik Pesantren: Sebuah Potret Perjalanan, Jakarta: Paramadina, 1997, h. 19-20.

10. Zamakhsyari Dhofier, loc. cit.

11. Tim Redaksi Kamus Besar Bahasa Indonesia, op. cit., h. 781.

12. Mastuhu, Dinamika Sistem Pendidikan Pesantren: Suatu Kajian tentang Unsur dan Nilai Sistem Pendidikan Pesantren, Jakarta: INIS, 1994, h. 55.

13. Abdullah Syukri Zarkasyi, Pondok Pesantren sebagai Alternatif Kelembagaan Pendidikan untuk Program Pengembangan Studi Islam Asia Tenggara, Surakarta: Universitas Muhammadiyah, 1990, h. 10.

14. Ibid., h. 79 .

15. Imam Bawani, Tradisional dalam Pendidikan Islam, Surabaya: al-Ikhlas, 1993, h. 89.

16. M. Amin Haedari, op. cit., h. 28.

17. Zamakhsyari Dhofier, op. cit., h. 93.

18. Bahaking Rama, Jejak Pembaharuan: Pendidikan Pesantren: Kajian Pesantren As'adiyah Sengkang Sulawesi Selatan, Jakarta: Parodatama, 2003, h. 39.

19. Zamakhsyari Dhofier, op. cit., h. 94.

20. M. Amin Haedari, op. cit., h. 30.

21. Zamakhsyari Dhofier, op. cit., h. 88; Lihat juga M. Amin Haedari, op. cit., h. 35.

22. M. Amin Haedari, ibid.; Lihat juga Zamakhsyari Dhofier, ibid., h.89.

23. Hampir semua kiai atau ulama di Jawa yang memimpin sebuah pesantren besar, memperdalam pengetahuan dan memperluas penguasaan ilmu agamanya dengan cara mengembara dari pesantren ke pesantren (berkelana). Setelah pesantren mengadopsi sistem pendidikan modern seperti sekolah atau madrasah, tradisi kelana ini mulai ditinggalkan. M. Amin Haedari, ibid., h. 37.

24. Zamakhsary Dhofier, op. cit., h. 89-90.

25. Bahaking Rama, op. cit. h. 38.

26. Ibid.

27. Zamakhsyari Dhofier, op. cit., h. 87.

28. Ibid. h. 85.

29. M.T. Houthma, Ensiklopedi of Islam, Leiden: E.J. Brill, 1934, h. 330-331.

30. Zamakhsyari Dhofier, loc. cit.

31. Ibid., h. 86.

32. Muljono Damopolii, Pesantren Modern IMMIM Pencetak Muslim Modern, Jakarta: Rajawali Press, 2011, h. 69.

33. Zamakhsyari Dofier, op. cit., h. 82-83. 
34. M. Amin Haedari dkk., Masa Depan Pesantren: dalam Tantangan Moderintas dan Tantangan Komplesitas Global, Cet. I; Jakarta: IRD Press, 2004, h. 6-7; Marwan Saridjo, Pendidikan Islam dari Masa ke Masa: Tinjauan Kebijakan Publik terhadap Pendidikan Islam di Indonesia, Cet. II; Bogor: Yayasan Ngali Aksara dan al-Manar Press, h. 30.

35. M. Amin Haedari, ibid., h. 10-11.

36. Ibid., h. 11.

37. Zamakhsyari Dhofier, op. cit., h. 75.

38. Ibid., h. 75-76.

39. Ibid., h. 78.

40. M. Amin Haedari, op. cit., h. 14-15.

41. Ibid., h. 15.

42. Metode halaqah merupakan kelompok kelas dari sistem bandongan. Halaqah berarti lingkaran peserta didik, atau sekolompok santri yang belajar di bawah bimbingan ustad dalam satu tempat. Pada prakteknya, halaqah dikateorikan sebagai diskusi untuk memahami isi kitab, bukan mempertanyakan kemungkinan benar salahnya apa yang diajarkan oleh kitab tersebut. M. Amin Haedari, ibid., h. 16.

43. Ibid., h.17-22.

44. Ibid., h. 22.

45. Marwan Saridjo, Pendidikan Islam dari Masa ke Masa: Tinjauan Kebijakan Publik terhadap Pendidikan Islam di Indonesia, Cet. II; Bogor: Yayasan Ngali Aksara dan al-Manar, 2011, h. 40.

46. Marwan Saridjo, Sejarah Pondok Pesantren di Indonesia, Jakarta: Dharma Bhakti, 1979, h. 4445.

47. Bahaking Rama, op. cit., h. 45.

48. Zamakhsyari Dhofier, op. cit., h. 79.

49. M. Amin Haedari, op. cit., h. 24-25; lihat Bahaking Rama, loc. cit.

50. M. Amin Haedari, ibid., h. 25.

51. Husni Rahim, Madrasah dalam Politik Pendidikan di Indonesia, Ciputat: PT Logos Wacana Ilmu, 2005, h.76.

\section{DAFTAR PUSTAKA}

Bawani, Imam. Tradisional dalam Pendidikan Islam. Surabaya: al-Ikhlas, 1993.

Damopolii, Muljono. Pesantren Modern IMMIM Pencetak Muslim Modern. Jakarta: Rajawali Press, 2011.

Departemaen Agama RI, Al-Qur'an dan Terjemahnya. Bandung: CV Diponegoro, 2010.

Dhofier, Zamakhsyari. Tradisi Pesantren: Studi Pandangan Hidup Kiai dan Visinya Mengenai Masa Depan Indonesia. Cet. IX; Jakarta: LP3ES, 2011.

Haedari, M. Amin, dkk. Masa Depan Pesantren: Dalam Tantangan Moderintas dan Tantangan Komplesitas Global. Cet. I; Jakarta: IRD Press, 2004.

Houthma, M.T. Ensiklopedi of Islalm. Leiden: E.J. Brill, 1934.

Madjid, Nurcholish. Bilik-Bilik Pesantren: Sebuah Potret Perjalanan. Jakarta: Paramadina, 1997.

Marwan. Sejarah Pondok Pesantren di Indonesia. Jakarta: Dharma Bhakti, 1979.

Mastuhu. Dinamika Sistem Pendidikan Pesantren: Suatu Kajian tentang Unsur dan Nilai Sistem Pendidikan Pesantren. Jakarta: INIS, 1994.

Poerbakawatja, Soegarda. Ensiklopedi Pendidikan, Jakarta: Gunung Agung, 1976.

Rahim, Husni. Madrasah dalam Politik Pendidikan di Indonesia. Ciputat: PT Logos Wacana Ilmu, 2005. 
Rama, Bahaking. Jejak Pembaharuan: Pendidikan Pesantren: Kajian Pesantren As'adiyah Sengkang Sulawesi Selatan. Jakarta: Parodatama, 2003.

Saridjo, Marwan. Pendidikan Islam dari Masa ke Masa: Tinjauan Kebijakan Publik terhadap Pendidikan Islam di Indonesia. Cet. II; Bogor: Yayasan Ngali Aksara dan al-Manar Press.

Shihab, M. Quraish. Membumikan al-Qur'an. Bandung: Mizan, 1992. . Wawasan al-Qur'an. Cet. II; Bandung: Mizan, 1996.

Tim Redaksi Kamus Besar Bahasa Indonesia, Kamus Besar Bahasa Indonesia. Edisi II. Jakarta: Balai Pustaka, 1991.

Zarkasyi, Abdullah Syukri. Pondok Pesantren sebagai Alternatif Kelembagaan Pendidikan untuk Program Pengembangan Studi Islam Asia Tenggara. Surakarta: Universitas Muhammadiyah, 1990. 